\title{
Candidate genes for production traits in Nelore beef cattle
}

\author{
P.C. Tizioto ${ }^{1}$, S.L. Meirelles ${ }^{2}$, R.R. Tulio ${ }^{3}$, A.N. Rosa ${ }^{4}$, M.M. Alencar ${ }^{3}$, \\ S.R. Medeiros ${ }^{4}$, F. Siqueira ${ }^{4}$, G.L.D. Feijón ${ }^{4}$, L.O.C. Silva ${ }^{4}$, \\ R.A.A. Torres Junior ${ }^{4}$ and L.C.A. Regitano ${ }^{3}$ \\ ${ }^{1}$ Departamento de Genética e Evolução, \\ Universidade Federal de São Carlos, São Carlos, SP, Brasil \\ ${ }^{2}$ Departamento de Zootecnia, Universidade Federal de Lavras, \\ Lavras, MG, Brasil \\ ${ }^{3}$ Embrapa Pecuária Sudeste, São Carlos, SP, Brasil \\ ${ }^{4}$ Embrapa Gado de Corte, Campo Grande, MS, Brasil
}

Corresponding author: L.C.A. Regitano

E-mail: luciana@cppse.embrapa.br

Genet. Mol. Res. 11 (4): 4138-4144 (2012)

Received January 20, 2012

Accepted June 6, 2012

Published September 19, 2012

DOI http://dx.doi.org/10.4238/2012.September.19.1

\begin{abstract}
Meat quality is an important trait for the beef industry. Backfat thickness, ribeye area, and shear force are traits measured late in life, and the investigation of molecular markers associated with these traits can help breeding programs. In cattle, some polymorphisms have been related to production traits. Thus, the purpose of this study was to assess the presence of polymorphisms in the candidate genes insulinlike growth factor 1 ( IGF1), fatty acid-binding protein 4 (FABP4), and peroxisome proliferative active receptor gamma coactivator $1 \mathrm{~A}$ (PPARGC1A) and associate them with production traits in reference families of Nelore cattle. We used 270 steers descendent from 20 sires that were chosen to represent variability in this breed. The investigation of marker effects on the traits was performed using a mixed model under the restricted maximum likelihood method. A significant allele substitution effect was found for $I G F 1$ and yearling weight $(\mathrm{P} \leq 0.017)$.
\end{abstract}


The mean allele substitution effect was $6.9 \mathrm{~kg}$, with the 229 allele associated with reduced yearling weight in this Nelore population.

Key words: Polymorphisms; Insulin-like growth factor; Bos indicus; Yearling weight

\section{INTRODUCTION}

Because Brazil is a world-leading producer of beef, interest in improving economically important production traits has been growing because despite the high economic potential of beef cattle, Brazilian competitiveness in national and international markets is based on low prices. Conducting studies to understand the genetic variation of carcass, meat quality, and growth traits is necessary to outline plans to improve such attributes. Along with traditional selection methods, which have achieved significant results, marker-assisted selection can help improve profiles for economically important traits earlier in the breeding cycle. The Brazilian cattle herd consists mainly of Zebu cattle, and the Nellore is the most relevant beef breed. Therefore, developing markers for this breed is expected to have a significant impact on the Brazilian beef industry.

The genes insulin-like growth factor 1 (IGF1), fatty acid-binding protein 4 (FABP4), and peroxisome proliferative active receptor gamma coactivator $1 \mathrm{~A}(P P A R G C 1 A)$ are candidates for influencing production traits in cattle. This study investigated the presence of polymorphisms in these candidate genes in the Nelore breed and their associations with the economic important traits backfat thickness (BFT), ribeye area (REA), Warner-Bratzler shear force (WBSF), weaning weight (WW), and yearling weight (YW).

\section{MATERIAL AND METHODS}

\section{Animals and phenotypic data}

Two hundred and seventy Nelore steers descendent from 20 sires chosen to represent the main genealogies marketed in Brazil were used for this study. The half-sibling families were produced via artificial insemination in commercial and purebred Nelore dams. The animals were raised on 3 farms and at approximately 18 months of age were allocated to 2 feed-

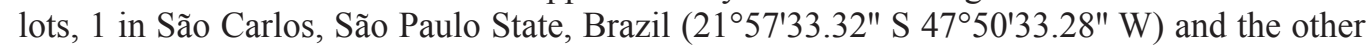

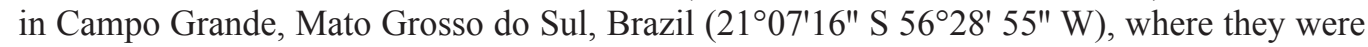
maintained for 90 to 130 days. For the analysis of WBSF, only the animals that were allocated to São Carlos (approximately 140) were used.

The steers were fed corn silage with at least $35 \%$ dry matter and high grain content plus a concentrate containing milled corn grain, soybean meal, limestone, mineral mixture, urea, and monensin (Rumensin ${ }^{\circledR}$ by Elanco-United States of America, USA). The diet, provided twice daily, was formulated to contain $13 \%$ crude protein and $71 \%$ of the estimated total digestible nutrients in a proportion of $60 \%$ whole plant corn silage and $40 \%$ concentrate. The amount of feed offered (total mixture composed of corn silage + concentrate) was adjusted by the feed remaining, ensuring that the steers were fed ad libitum.

Before entering feedlots, WW and YW (weight at 16 months of age on average) were 
recorded. WW and YW were adjusted to 240 and 450 days, respectively. Twenty-four hours after slaughter, $2.5-\mathrm{cm}$ thick steaks corresponding to a cross-section of the longissimus dorsi muscle between the 12th and 13th ribs were collected. Steaks were identified, vacuum packed, and used to measure BFT, REA, and WBSF. BFT was measured with a ruler, and REA was measured with a grid. WBSF was measured using a TA-XT2i Texture Analyzer coupled to a Warner-Bratzler blade with $1.016 \mathrm{~mm}$ in thickness. The analyses of WBSF were carried out at various maturation times: approximately $24 \mathrm{~h}$ after slaughter $(\mathrm{t}=0)$ and after $7(\mathrm{t}=7)$ and 14 days $(t=14)$ of maturation in a cold chamber.

\section{DNA extraction and genotypic data}

Straws of frozen semen obtained from Brazilian artificial insemination centers were used to extract DNA from bulls using a standard phenol-chloroform method. For the steers, 5 $\mathrm{mL}$ blood was used, and DNA extractions were carried out using a salting-out method.

From previous reports of effects on production traits (Bishop et al., 1994; Weikard et al., 2005; Cho et al., 2008), 3 candidate genes were selected for analysis. To amplify the promoter region of the $I G F 1$ gene, which contains the microsatellite repeat $(\mathrm{CA})_{\mathrm{n}}$, primers described by Bishop et al. (1994) were used, and the forward primer was labeled with fluorescence. Polymerase chain reaction (PCR) was carried out with $1 \mathrm{X}$ reaction buffer, $1.5 \mu \mathrm{M}$ $\mathrm{MgCl}_{2}, 0.2 \mathrm{mM}$ each deoxyribonucleotide triphosphate, $0.1 \mu \mathrm{M}$ of each primer, $0.5 \mathrm{U}$ Taq DNA polymerase, and $20 \mathrm{ng}$ DNA in a final volume of $5 \mu \mathrm{L}$.

The amplification steps were $3 \mathrm{~min}$ of initial denaturation at $94^{\circ} \mathrm{C}$, followed by $30 \mathrm{cy}-$ cles of $94^{\circ}, 56^{\circ}$, and $72^{\circ} \mathrm{C}$ for $30 \mathrm{~s}$, and a final extension step at $72^{\circ} \mathrm{C}$ for $45 \mathrm{~min}$. The polymorphisms of PPARGC1A and FABP4 were genotyped with PCR-restriction fragment length polymorphism. To genotype the single-nucleotide polymorphism (G/A) in exon 2 of the FABP 4 gene (Cho et al., 2008), we designed primers - forward, 5'-AATACACACACACACACCTGCTC3', and reverse, 5'-GAATGGCTTTCCTCCTTCTACA-3' - and used the restriction enzyme $\mathrm{NmuCI}$. PCR was performed in $20-\mu \mathrm{L}$ reactions with $1 \mathrm{X}$ buffer reaction, $1.5 \mathrm{mM} \mathrm{MgCl}{ }_{2}, 0.2$ $\mathrm{mM}$ of each deoxyribonucleotide triphosphate, $0.4 \mu \mathrm{M}$ of each primer, $1 \mathrm{U}$ Taq DNA polymerase, and 100 ng genomic DNA. Thermal cycling conditions included an initial denaturation step at $94^{\circ} \mathrm{C}$ for $2 \mathrm{~min}$ followed by 35 cycles of $94^{\circ}, 60^{\circ}$, and $72^{\circ} \mathrm{C}(30 \mathrm{~s}$ each $)$ and a final extension step at $72^{\circ} \mathrm{C}$ for $7 \mathrm{~min}$. Digestion of the PCR product ( $353 \mathrm{bp}$ ) with the restriction enzyme $\mathrm{NmuCI}$ revealed 2 alleles.

Animals with the GG genotype had a substitution of adenine by guanine in exon 2, which produced an additional restriction site in the amplified region and caused a pattern of 3 restriction fragments $(72,121$, and $160 \mathrm{bp})$. Genotype AA was characterized by a restriction pattern of 2 fragments (160 and $193 \mathrm{bp}$ ). Heterozygous animals showed a combination of the 2 patterns with 4 fragments. A 179-bp region of the bovine PPARGC1A gene containing the SNP in intron 9 (c.1892+19T $>$ C) was genotyped according to a method described by Weikard et al. (2005) using the restriction enzyme BsuRI. The reverse primer was labeled for the analysis of PCR products and fragments were digested using an ABI Prism 3100 Avant sequencer (Applied Biosystems). Genotypes were determined using GeneScan (version 3.7.1). Animals with the TT genotype displayed a substitution of cytosine by thymine, which removed the restriction site of the enzyme in the amplified region and caused a pattern of undigested PCR product (179 bp). Animals with the CC genotype were characterized by the presence of the 
restriction site and showed 2 fragments (20 and $159 \mathrm{bp}$ ). A combination of these 2 patterns was seen in heterozygotes.

\section{Statistical analysis}

Deviations from Hardy-Weinberg equilibrium were analyzed using a probability test according to a method described by Raymond and Rousset (1995). To evaluate the influence of markers on BFT, REA, YW, WW, and WBSF, we used a mixed model with fixed effects of contemporary groups and genotypes and the age of the animal at measurement (linear effect) as a covariate in addition to the random effect of the bull. The contemporary groups for BFT and REA included the effects of birthplace, place of confinement, and month of birth. For YW and WW, the effects of place and month of birth were included, and for WBSF, the effects of birthplace and place of confinement, month of birth, and slaughter batch were also included. For WBSF the $\mathrm{pH}$ measured in the meat $24 \mathrm{~h}$ after slaughter was included as a covariate.

Analyses were performed with restricted maximum likelihood using PROC MIXED in the Statistical Analysis System (SAS Institute Inc., 2000) with the following Equation:

$$
\mathrm{Y}_{\mathrm{ijklm}}=\mu+\mathrm{GC}_{\mathrm{i}}+\mathrm{M}_{\mathrm{j}}+\mathrm{T}_{\mathrm{k}}+\mathrm{b} 1\left(\mathrm{I}_{\mathrm{ijkl}}\right)+\mathrm{e}_{\mathrm{ijkkm}}
$$

(Equation 1)

where $Y_{i j k l m}$ is the phenotype of the $\mathrm{m}^{\text {th }}$ individual, of age I son of the $\mathrm{k}^{\text {th }}$ bull, of $\mathrm{j}^{\text {th }}$ genotype for the marker, belonging to the $\mathrm{i}^{\text {th }}$ contemporary group; $\mu$ is the overall mean; $G C_{i}$ is the fixed effect of the $\mathrm{i}^{\text {th }}$ contemporary group; $M_{j}$ is the fixed effect of $\mathrm{j}^{\text {th }}$ genotype for the marker; $T_{k}$ is the random effect of the father of the $\mathrm{k}^{\mathrm{th}}$ animal; $b 1$ is the regression coefficient on the age of an animal; $I_{i j k l}$ is the age of the $\mathrm{I}^{\text {th }}$ animal on the date of measurement, and $e_{i j k l m}$ is the random error associated with each observation $\mathrm{i}_{\mathrm{jklm}}$, assumed to be normally distributed with mean zero and variance $\sigma^{2}$. When marker genotype effects were suggestive $(\mathrm{P} \leq 0.10)$, we estimated the allele substitution effect by replacing the marker genotype effect for covariates corresponding to the number of copies of a given allele in the statistical model.

\section{RESULTS AND DISCUSSION}

All of the possible genotypes for the SNPs in FABP4 and PPARGC1A were found in this population (Table 1). For the microsatellite $I G F 1$, only 2 alleles, 225 and $229 \mathrm{bp}$, were found, and the most frequent was the former. The alleles 227 and $231 \mathrm{bp}$ previously described for this microsatellite (Regitano et al., 1999) were not observed.

The protein encoded by the gene IGFI has a function and structure similar to that of insulin and is a member of a family of proteins involved in mediating growth and development and participating in cell differentiation, embryogenesis, growth, and regulation of metabolism. $I G F 1$ is a candidate for growth rates and production traits in beef cattle. According to Islam et al. (2009), several studies have identified a quantitative trait locus (QTL) associated with carcass traits in the vicinity of $I G F 1$ in beef cattle. Several studies have associated polymorphisms in $I G F 1$ with growth traits in beef cattle as well (Pereira et al., 2005; Andrade et al., 2008). Islam et al. (2009) have associated an SNP in the promoter region of IGF1, the same region in which the microsatellite used in this study resides with fat deposition and other carcass traits in crossbred Angus and Charolais beef cattle. Although we found no significant associa- 
tion between $I G F 1$ genotypes and growth traits $(\mathrm{P} \leq 0.05$; Table 2$)$ in the present study, the allele substitution effect was significant $(\mathrm{P}=0.017)$ on $\mathrm{YW}$. The mean allele substitution effect was $6.9 \mathrm{~kg}$, with the 229 allele associated with reduced $\mathrm{YW}$ in this Nelore population. Pereira et al. (2005) have investigated the effect of the IGF1 microsatellite studied here on growth traits in a Canchim beef cattle population. The authors found a positive average substitution effect of the IGF1 225-bp allele on birth weight and of the 229-bp allele on YW. Our results showed that the 225 allele was positively correlated with $\mathrm{YW}$, which suggests that the effects of IGF1 alleles are different for different breeds, populations, and growth stages. These results may be interpreted as if this marker is in linkage disequilibrium, with QTLs affecting the traits rather than being causal mutation effects. So the favorable allele in each genetic group must be investigated before implementing this marker for marker-assisted selection.

\section{Table 1. Allelic and genotypic frequencies of PPARGC1A, FABP4, and IGF1 markers.}

\begin{tabular}{lccccc}
\hline Markers & \multicolumn{2}{c}{ Allelic frequency (\%) } & \multicolumn{3}{c}{ Genotypic frequency (\%) } \\
\hline IGF1 & 225 & 229 & $225 / 225$ & $225 / 229$ & $229 / 229$ \\
& 73.55 & 26.45 & 54.34 & 38.41 & 7.25 \\
FABP4 & $\mathrm{A}$ & $\mathrm{G}$ & $\mathrm{AA}$ & $\mathrm{AG}$ & $\mathrm{GG}$ \\
& 17.51 & 82.49 & 1.9 & 31.0 & 67.10 \\
PPARGCIA & $\mathrm{C}$ & $\mathrm{T}$ & $\mathrm{CC}$ & $\mathrm{CT}$ & $\mathrm{TT}$ \\
& 85.4 & 14.6 & 72.2 & 26.36 & 1.44 \\
\hline
\end{tabular}

Table 2. Summary of the results of the mixed model analysis of association among the traits evaluated and the markers, estimated means, and standard errors for the traits by marker genotype.

\begin{tabular}{|c|c|c|c|c|c|c|c|}
\hline \multirow[t]{2}{*}{ Markers } & \multicolumn{7}{|c|}{ Traits } \\
\hline & $\begin{array}{l}\text { BFT } \\
(\mathrm{mm})\end{array}$ & $\begin{array}{l}\text { REA } \\
(\mathrm{mm})\end{array}$ & $\begin{array}{c}\mathrm{WBSF} / \mathrm{t}=0 \\
(\mathrm{~kg})\end{array}$ & $\begin{array}{c}\mathrm{WBSF} / \mathrm{t}=7 \\
(\mathrm{~kg})\end{array}$ & $\begin{array}{c}\mathrm{WBSF} / \mathrm{t}=14 \\
(\mathrm{~kg})\end{array}$ & $\begin{array}{l}\text { WW } \\
(\mathrm{kg})\end{array}$ & $\begin{array}{l}\mathrm{YW} \\
(\mathrm{kg})\end{array}$ \\
\hline \multicolumn{8}{|l|}{$\overline{I G F 1}$} \\
\hline $\mathrm{P}$ & 0.121 & 0.891 & 0.535 & 0.365 & 0.902 & 0.559 & 0.071 \\
\hline $225 / 225$ & $6.52 \pm 0.29$ & $59.91 \pm 0.87$ & $8.26 \pm 0.27$ & $5.35 \pm 0.26$ & $3.76 \pm 0.19$ & $190.9 \pm 2.0$ & $252.7 \pm 2.1$ \\
\hline $225 / 229$ & $7.06 \pm 0.32$ & $60.19 \pm 0.94$ & $8.54 \pm 0.26$ & $5.25 \pm 0.26$ & $3.71 \pm 0.19$ & $188.5 \pm 2.3$ & $245.9 \pm 2.3$ \\
\hline $229 / 229$ & $6.22 \pm 0.61$ & $59.50 \pm 1.68$ & $8.39 \pm 0.44$ & $4.72 \pm 0.44$ & $3.61 \pm 0.33$ & $186.2 \pm 5.5$ & $242.4 \pm 5.4$ \\
\hline \multicolumn{8}{|l|}{ FABP4 } \\
\hline $\mathrm{P}$ & 0.375 & 0.893 & 0.476 & 0.260 & 0.487 & 0.763 & 0.522 \\
\hline AA & $5.30 \pm 1.04$ & $61.47 \pm 3.0$ & $9.96 \pm 1.44$ & $6.53 \pm 1.62$ & $2.50 \pm 1.22$ & $194.3 \pm 9.6$ & $256.8 \pm 9.6$ \\
\hline $\mathrm{AG}$ & $6.65 \pm 0.34$ & $60.11 \pm 1.03$ & $8.31 \pm 0.28$ & $5.47 \pm 0.28$ & $3.81 \pm 0.21$ & $190.7 \pm 2.6$ & $250.3 \pm 2.5$ \\
\hline GG & $6.75 \pm 0.28$ & $60.04 \pm 0.86$ & $8.46 \pm 0.25$ & $5.08 \pm 0.23$ & $3.66 \pm 0.18$ & $189.0 \pm 1.8$ & $248.6 \pm 1.7$ \\
\hline \multicolumn{8}{|l|}{ PPARGCIA } \\
\hline$P$ & 0.743 & 0.108 & 0.673 & 0.910 & 0.661 & 0.285 & 0.774 \\
\hline $\mathrm{CC}$ & $6.66 \pm 0.28$ & $59.64 \pm 0.84$ & $8.45 \pm 0.23$ & $5.24 \pm 0.23$ & $3.72 \pm 0.17$ & $189.8 \pm 1.7$ & $249.6 \pm 1.7$ \\
\hline СT & $6.74 \pm 0.36$ & $61.28 \pm 1.06$ & $8.17 \pm 0.32$ & $5.25 \pm 0.33$ & $3.60 \pm 0.24$ & $188.9 \pm 2.8$ & $248.7 \pm 2.7$ \\
\hline TT & $5.87 \pm 1.16$ & $62.20 \pm 3.75$ & $7.95 \pm 0.98$ & $5.70 \pm 1.09$ & $2.10 \pm 0.81$ & $208.8 \pm 12$ & $250.2 \pm 12$ \\
\hline
\end{tabular}

$\mathrm{BFT}=$ backfat thickness; REA $=$ ribeye area; $\mathrm{WBSF}=$ Warner-Bratzler shear force; $\mathrm{WW}=$ weaning weight; $\mathrm{YW}$ $=$ yearling weight.

We found no significant association between $F A B P 4$ and the production traits studied. FABPs are members of a family of proteins that bind lipids. FABP 4, also known as adipocyte FABP, is located on bovine chromosome 14 in which QTLs for the meat production traits fat thickness, yield grade, and marbling have been reported (Casas et al., 2003). Studies have shown that FABP4 plays a critical role in fatty acid absorption and metabolism and seems to be involved in the hydrolysis of lipids (Michal et al., 2006). Our results contrast with those 
of Michal et al. (2006), who observed an association between this gene and marbling score and backfat deposition in a Wagyu $\mathrm{x}$ Limousin $\mathrm{F}_{2}$ population. Our results also conflict with those of Cho et al. (2008), who found an association between 2 SNPs in FABP4 including the one investigated in our study and fat deposition in steers from the progeny testing program of the National Livestock Research Institute of Korea. Our previous association analysis with backfat data obtained by ultrasound in this Nelore population (data not shown) suggested a significant association between this gene and BFT. However, the post-slaughter BFT data did not confirm this association, possibly owing to the incomplete correlation (0.6) that we found between BFT data obtained from ultrasound images and that gathered after slaughter.

In an association analysis between each trait studied and PPARGC1A, we found no significant associations (see Table 2). The PPARGC1A gene is involved in the adipocytokine and insulin-signaling pathways as well as in multiple biological responses related to energy homeostasis, thermoregulation, and glucose metabolism. This gene is a functional and positional candidate for influencing the development of obesity, according to the human genetic map of obesity (Snyder et al., 2004). The PPARGC1A gene has been mapped in humans to a region previously associated with serum insulin concentration and obesity; polymorphisms of this gene have been associated with insulin resistance, susceptibility to type II diabetes (Sun et al., 2006), and indicators of obesity (Semple et al., 2004). Studies performed by Puigserver and Spiegelman (2003) have shown that PPARGC1A has a key role in activating a variety of nuclear hormone receptors and transcription factors that regulate energy homeostasis. It is involved in mechanisms of adipogenesis and gluconeogenesis, making it a likely candidate to affect the amount and distribution of body fat. In pigs, PPARGC1A is considered a candidate gene for production traits. Stachowiak et al. (2007) have found an SNP in this gene associated with fat-related traits in swine. Weikard et al. (2005) have identified PPARGC1A in cattle as a positional candidate gene for its location in a region of bovine chromosome 6 that underlies a previously described QTL for fat deposition in milk. These authors have found an association between an SNP located in intron 9 of bovine PPARGC1A and milk production traits. Soria et al. (2009) have identified 2 SNPs in exon 8 of bovine PPARGC1A but found no association with production traits in beef cattle. For this population of Nelore, we also found no significant association between PPARGC1A and any of the traits studied.

If the significant effect of allele substitution on the IGF1 marker on $\mathrm{YW}$ is proven in other populations of Nelore, this information could be used in marker-assisted selection because it is a highly valorized production trait.

\section{ACKNOWLEDGMENTS}

We thank the farm Novo Horizonte in the State of Mato Grosso do Sul for breeding some of the animals for this project, MSc. Michele Lopes do Nascimento and MSc. Andrea Souza for monitoring the feedlots, CNPq for providing fellowships to M.M. Alencar and L.C.A. Regitano, and FAPESP for providing a scholarship to P.C. Tizioto.

\section{REFERENCE}

Andrade PC, Grossi DA, Paz CC, Alencar MM, et al. (2008). Association of an insulin-like growth factor 1 gene microsatellite with phenotypic variation and estimated breeding values of growth traits in Canchim cattle. Anim. Genet. 39: 480-485. 
Bishop MD, Kappes SM, Keele JW, Stone RT, et al. (1994). A genetic linkage map for cattle. Genetics 136: 619-639.

Casas E, Shackelford SD, Keele JW, Koohmaraie M, et al. (2003). Detection of quantitative trait loci for growth and carcass composition in cattle. J. Anim. Sci. 81: 2976-2983.

Cho S, Park TS, Yoon DH, Cheong HS, et al. (2008). Identification of genetic polymorphisms in FABP3 and FABP4 and putative association with back fat thickness in Korean native cattle. BMB Rep. 41: 29-34.

Islam KK, Vinsky M, Crews RE, Okine E, et al. (2009). Association analyses of a SNP in the promoter of IGF1 with fat deposition and carcass merit traits in hybrid, Angus and Charolais beef cattle. Anim. Genet. 40: 766-769.

Michal JJ, Zhang ZW, Gaskins CT and Jiang Z (2006). The bovine fatty acid binding protein 4 gene is significantly associated with marbling and subcutaneous fat depth in Wagyu x Limousin F2 crosses. Anim. Genet. 37: 400-402.

Pereira AP, Alencar MM, Oliveira HN and Regitano LCA (2005). Association of GH and IGF-1 polymorphisms with growth traits in a synthetic beef cattle breed. Genet. Mol. Biol. 28: 230-236.

Puigserver P and Spiegelman BM (2003). Peroxisome proliferator-activated receptor-gamma coactivator 1 alpha (PGC-1 alpha): transcriptional coactivator and metabolic regulator. Endocr. Rev. 24: 78-90.

Raymond M and Rousset F (1995). Genepop (version 1.2): Population genetics software for exact tests and ecumenicism. J. Hered. 86: 248-249.

Regitano LCA, Azevedo JL, Vencovsky R, Packer IU, et al. (1999). Selection for breed-specific growth hormone and IGF-1 alleles in a synthetic beef cattle cross, Canchim. Genet. Mol. Bio. 22: 531-537.

SAS Institute Inc. (2000). SAS Procedures Guide. Version 8. Cary.

Semple RK, Crowley VC, Sewter CP, Laudes M, et al. (2004). Expression of the thermogenic nuclear hormone receptor coactivator PGC-1alpha is reduced in the adipose tissue of morbidly obese subjects. Int. J. Obes. Relat. Metab. Disord. 28: 176-179.

Snyder EE, Walts B, Perusse L, Chagnon YC, et al. (2004). The human obesity gene map: the 2003 update. Obes. Res. 12: 369-439.

Soria LA, Corva PM, Branda SA, Villarreal EL, et al. (2009). Association of a novel polymorphism in the bovine PPARGC1A gene with growth, slaughter and meat quality traits in Brangus steers. Mol. Cell Probes 23: 304-308.

Stachowiak M, Szydlowski M, Cieslak J and Switonski M (2007). SNPs in the porcine PPARGCla gene: interbreed differences and their phenotypic effects. Cell Mol. Biol. Lett. 12: 231-239.

Sun L, Yang Z, Jin F, Zhu XQ, et al. (2006). The Gly482Ser variant of the PPARGC1 gene is associated with Type 2 diabetes mellitus in northern Chinese, especially men. Diabet. Med. 23: 1085-1092.

Weikard R, Kuhn C, Goldammer T, Freyer G, et al. (2005). The bovine PPARGC1A gene: molecular characterization and association of an SNP with variation of milk fat synthesis. Physiol. Genomics 21: 1-13. 